\title{
Situational Diagnostics Using a Maturity Model in High Education Institutions
}

\author{
Daniel Fernando Antonucci e Silva ${ }^{1}$, Rodrigo Becke Cabral ${ }^{1}$, Glauson de Moraes Mendes ${ }^{2}$ \\ ${ }^{1}$ Cadsoft - GAM, Brazil \\ ${ }^{2}$ Itechnologies, Brazil
}

\begin{abstract}
The segment of education in Brazil, especially in higher education, has undergone major changes. The search for professionalization, for cost reduction and process standardization has led many institutions to develop partnerships or make acquisitions. On the other hand, maturity models have been successfully used in several areas of knowledge especially in software development, as an approach for quality models. This paper presents a methodology to evaluate the maturity of academic process management in private institutions of higher education through a Situational analysis and the benefits that can be achieved.

This methodology was designed for the Brazilian market, but its idea can be applied to a global maturity model of academic process management.
\end{abstract}

\section{Introduction}

The segment of Brazilian education has undergone major changes in the last ten years in pursuit of development and consolidation of this market. Education institutions have become professionalized, seeking capital in the stock market and adopting marketing concepts, management and strategic planning, marketing planning, BSC and others [1]. A small group of institutions positioned themselves as "consolidators" of the market, growing by acquisitions of other institutions and developing strategic partnerships to expand to markets where they would have any presence. However, it is important to note that quality management in education is a challenge not only in Brazil, but worldwide, as can be noticed in the text of Tucci [2] "Quality implementation in higher education institutions is a great challenge in all Europe, especially after Bologna Declaration (1999).”

Brazilian Government has also aggravated the pressure for the growth of the country with its PAC (Program for Acceleration of Growth), which deepens the need for generation of qualified workforce in shorter learning cycles and affordable learning programs for the whole population. However, analyzing the process of this segment without assessing the global context can be misleading. For McGrew [3] Globalization refers to those processes, acting on a global scale, crossing national borders, integrating and connecting communities and organizations in new combinations of space-time, making the world in reality and in experience more interconnected. Thus it is necessary to seek global solutions to local problems.

In addition, the government, with a defined positioning for investment in public education has expanded, through the Ministry of Education and Culture (MEC), that regulates the opening and closing of institutions and programs; and define methods for an institution to continue working or offering certain programs. In recent years concepts have been created as: ENADE, IGC, CPC, all under the aegis of SINAES [1], specific legislation to:

- Ensure the national process of evaluation of higher education institutions with the cooperation of the systems that have responsibility for this level of education;

- Authorize, recognize, accredit, monitor and evaluate, respectively, the programs of higher education institutions and methods of its education system.

In addition to this complex situation, there are also the representative institutions that want, through the association of Private Institutions of Higher Education (PIHE), to have a unique position to the government when it comes to regulations and controls that are being created, which often in view of these institutions are difficult and expensive, without necessarily improving the quality of Brazilian higher education. Figure 1 summarizes the current situation of most of the PIHE and the pressures faced by these.

This scenario suggests that the segment is receptive to the development of audit standards and quality, and therefore, a maturity model can become a tool to ensure continuous evaluation and 
comparison, and underpin the decision making of managers of these institutions.

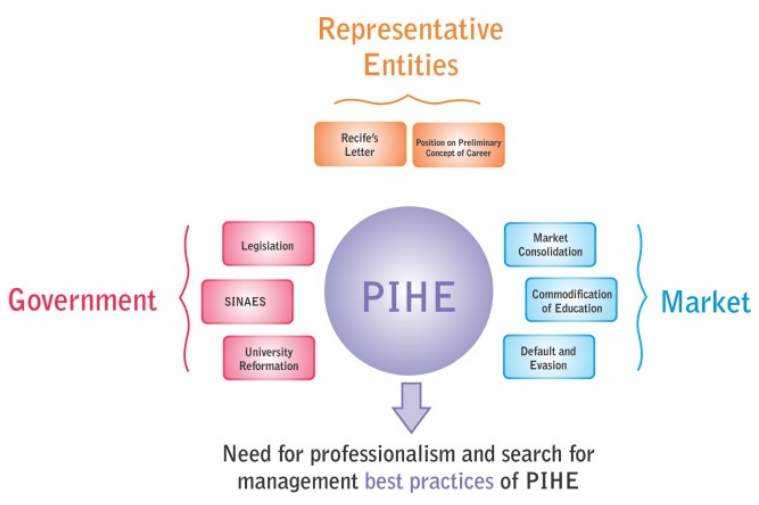

Figure 1. Pressure suffered by IPES

As stated by Silva, Cabral e Colenci Jr [4], "the studies indicate that, currently, there is no standard definition of maturity levels of academic management processes, also pointing the lack of mechanisms for assessing the maturity".

Therefore, the proposed model presented in this article brings to the segment of education, the concepts of maturity models that have emerged over the years, as part of the development of quality models and audit organizations. By definition, a maturity model is a structured collection of elements that describe certain aspects of the maturity of an organization [1]. A maturity model provides, for example:

- A starting point for a quality program, allowing us to track the progress of the improvements achieved;

- The benefits of learning from past experience, reusing the knowledge of individuals and organizations;

- A common vocabulary and a shared vision, enabling the development of best practices;

- A framework for prioritizing actions, reducing costs and increasing the effectiveness of work;

- A way to define the most significant improvements to an organization, creating an abstract view of what should be done.

The Maturity Model Process is identified by Silva [1] to:

- Assess the ability of processes in achieving their goals;

- $\quad$ Find opportunities to improve productivity and quality and reduce costs;

- Plan and monitor the actions of continuous improvement of business processes;

- Evaluate different organizations and make comparisons between them;
The mainly benefits brought to the higher education institutions by this maturity model are:

- Greater satisfaction from teachers and students through:

o An adoption of practices designed for the reality of education that enable the delivery of quality services;

0 Continuous generation of results that encourage a positive perception of teachers and students aggregated to institutional image;

- Process Optimization and Cost Reduction through:

o Reusing knowledge between individuals and institutions;

o A common vocabulary and a shared vision in the development of best practices;

o A capacity assessment processes in achieving their goals

o A planning and monitoring of actions for continuous improvement of institutional processes;

- Greater transparency and reliability in business through:

o A starting point for a quality program, allowing all to follow the progress of the improvements achieved;

o An integrated and holistic view of the institution that enhances the process of decision making;

o An evaluation of different organizations to make comparisons between them.

\section{Elements of the Proposed Model}

According to the proposed Maturity Model there are four axis elements that give sustainability to implementation and evaluation of academic processes management in private institutions of higher education [5]. These elements were defined according to academic studies and field experimentation in the implementation and improvement of management processes in Brazilian institutions. The four elements are:

- $\quad$ Processes of Academic Management

- $\quad$ Expected Results of Process (ERPs)

- Attributes of Processes Results (APRs)

- Maturity Scale 


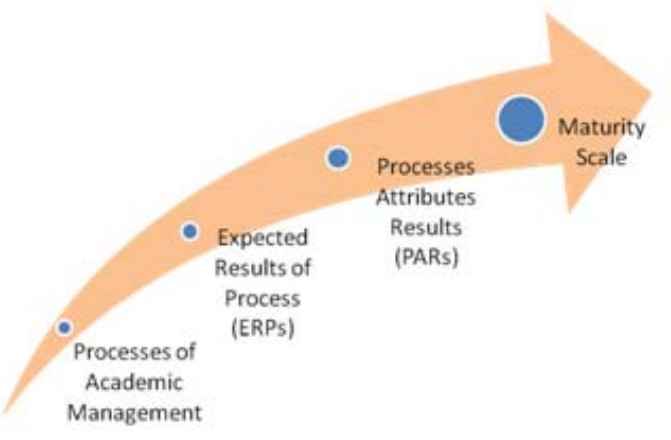

Figure 2. Graphical representation of the elements of the Maturity Model

\section{Process of Academic Management}

The ISO / IEC 15504-5, 2006 [6], used in this Maturity Model, is a reference to format the academic process management and determine the characteristics necessary for the existence of a process, which are:

- $\quad$ Process identifier;

- Process name;

- $\quad$ Process purpose;

- Outcomes;

- $\quad$ Base practice;

- Work-products;

For this Maturity Model four out of six characteristics of the process were chosen, which are:

- $\quad$ Process identifier;

- $\quad$ Process name;

- $\quad$ Process purpose;

- $\quad$ Outcomes (Expected Process Results - EPRs)

The "best practices" and "work products" are addressed by a complimentary methodology, not described in this paper, for the implementation of processes and operational flows that support the development, improvement and consolidation of operational management process of a private institution of higher education. The Processes of Academic Management are aligned with planning levels of educational institutions, which are operational, tactical and strategic. This relationship can be better understood in figure 3. It is important to note that the Maturity Model for Academic Process Management covers the strategic and tactical levels while the models of deployment of processes and operational flows should cover the operational level.

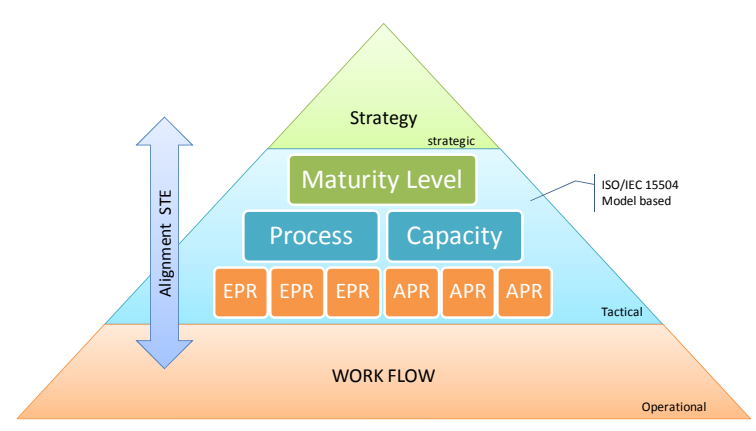

Figure 3. Alignment between the structure of processes and levels of planning in organizations

The purpose of an academic process management establishes three important elements of planning organizations, which are:

- The purpose of the academic process management;

- How it helps the institution to achieve its goals;

- The future scenario that will be achieved after the implementation of the process

Through the purpose of the academic process management it is possible to reach the connection with the educational institution strategy that must be established through its own strategic planning.

In 2010, the Maturity Model of Academic Process Management [9] was improved and now provides 22 processes, distributed in a new format. For believe that institutions of higher education has two mainly dimensions, called academic management and corporate management and like any other company in the world has three structural levels, known as strategic, tactical and operational, the maturity model distributed processes of academic management in a matrix with four quadrants called "Coverage Map". The four dimensions of this map are:

- Academic management - used to indicate the process used to manage academic domain. These processes are specific for academic institutions.

- Corporate management - used to indicate the process used to manage the corporate domain. These processes are common in great part of companies.

- Strategic team - used to indicate the board of the institution, where the strategic plan and longterm decisions are taken

- Operational team - used to indicate the employees that must put the strategy into action 
Figure 4 shows how the academic processes are distributed in the Coverage Map.

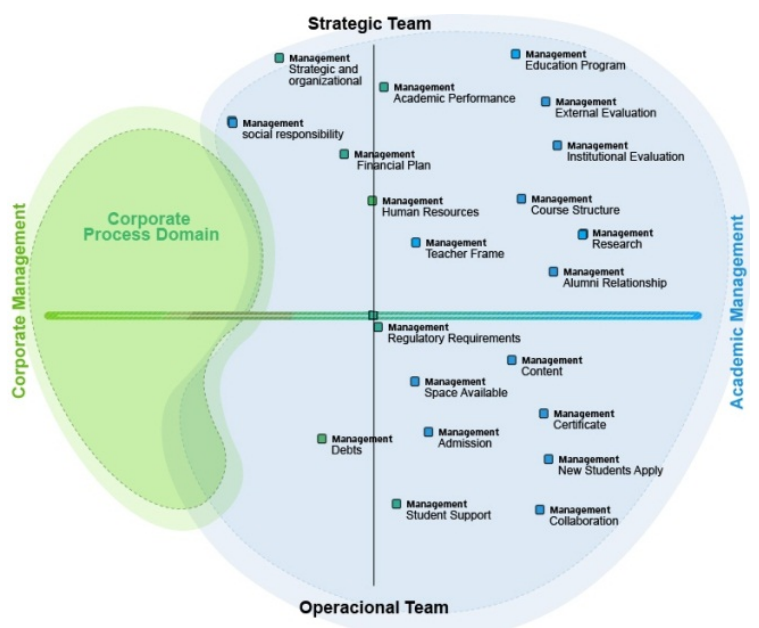

Figure 4.The Coverage Map of Academic Process

In addition, these academic processes are distributed in a maturity scale that will be presented in Chapter 6.

List of academic processes:

- Education Program Management

- $\quad$ Teacher Practice Management

- Financial Plan Management

- Regulatory Requirements Management

- Student Relationship Management

- Space Available Management

- New Students Apply Management

- Course Structure Management

- Content Management

- Admission Management

- Certificate Management

- Assessment and Attendance Management

- Collaboration Management

- Debts Management

- Institutional Evaluation Management

- External Evaluation Management

- Alumni Relationship Management

- Academic Performance Management

- Human Resources Management (new)

- $\quad$ Strategic and Organizational Management (new)

- $\quad$ social responsibility management (new)

- $\quad$ Research management (new)

\section{Expected Process Results (EPRs)}

The expected results [5] allow the process to be measured by their results achieved or not achieved by the process of academic management in question. Each expected result is broken down into items, called goals set, and each goal set presupposes the existence of evidence showing that the goal was achieved.

The goals set can have four stages of situational diagnostics, which are:

- Achieved - When the evidence shows that the objective was fully met;

- Not achieved - When there is no evidence showing that the goal set is met;

- $\quad$ Partially achieved - When the evidence shows that only part of the goal was met;

- Does Not Apply- Occurs when a goal set has a specific feature and that is not practiced by the institution.

Table 1 helps to understanding how the goals set should be evaluated:

Table 1. Goals set for an example of EPR with the simulation of an evaluation

\begin{tabular}{|l|l|}
\hline Goals Set & Status \\
\hline The fixed costs of career are set & Achieved \\
\hline The variables costs of career are set & Achieved \\
\hline $\begin{array}{l}\text { The direct and indirect expenses are } \\
\text { leared }\end{array}$ & Achieved \\
\hline $\begin{array}{l}\text { The investments required for opening } \\
\text { and / or maintenance of the career } \\
\text { are planned }\end{array}$ & Achieved \\
\hline $\begin{array}{l}\text { The career coordinator actively } \\
\text { participate in the process of career } \\
\text { financial management }\end{array}$ & $\begin{array}{l}\text { Not } \\
\text { Achieved }\end{array}$ \\
\hline
\end{tabular}

After analyzing the processes of an institution, during the diagnostic, must be made recommendations to ensure that all goals set of a particular ERP (Expected Results of Process) will be reached. The recommendations may also be suggested to improve the process that the goals set were met.

\section{Attributes of Processes Results (APRs)}

The ability of a process [5] to generate results is determined by a group of attributes described in terms of good working practices. The capability of the process shows the degree of professionalism and seriousness of a process running in an education institution. As the institution develops itself in the scale of maturity, a wider group of control practices for implementing the process should be performed. 
The practices determined by the Attributes of Processes Results (APRs) must be performed for all processes of the maturity level corresponding. To the extent that an institution evolves in the scale of maturity, the APRs that are already running should be applied to the new academic process management included in the maturity level that the institution intends to achieve.

Each Attributes of Processes Results (APRs) contains:

- Identification

- Definition

- Goals set

For this maturity model is proposed 5 APRs, and one for each level in the maturity scale, which are:

APR1 - The process achieves its defined purpose

- The process is executed and achieves its purpose

- The goals set for the process are implemented and proven

APR2 - The process implementation is managed

- The process implementation is planned

- The resources needed to implement the process are identified and made available

- People who perform process tasks are competent and proficient

APR3 - The process is measured

- The implementation of the process is monitored and adjustments are made to meet the plans

- Measures are planned and collected for monitoring the implementation of the process

- The results of the work are evaluated objectively in relation to standards, procedures and requirements and non-conformities are addressed

- Measures and the frequency of the measurements are identified and defined in accordance with the objectives of the process measurement

- $\quad$ Results of measurements are collected, analyzed and used to characterize the performance of the process

APR4 - The process is controlled

- Measurement data are analyzed and the variations are observed

- Corrective actions are taken to address special causes of variation

- Models of process performance are established and maintained

APR5 - The process is continuously optimized

- The impact of the proposed changes is assessed in relation to the objectives of the process
- The implementation of all agreed changes are managed to ensure that any change in process performance is understood and are taken pertinent actions

- The effectiveness of the changes, taking into account their performance resulting, is evaluated with respect to product requirements and goals of the process

The organization of ERPs and APRs in the maturity scale determines finally the Maturity Model for Process of Academic Management.

\section{Maturity Scale}

The maturity scale is the last element of the Maturity Model for Academic Process Management that unifies other elements of the model. Through the relationship between the level of maturity, the process of academic management and its expected results and finally the process attributes, is possible to assess the maturity level of an institution and compare it against the levels of maturity between different institutions.

Table 2 shows the maturity scale of the Maturity Model for Process of Academic Management in its preliminary version, adapted from CMM [7] and CMMI [8].

Table 2. Maturity Scale of of the Maturity Model for Academic Process Management

\begin{tabular}{|c|c|c|}
\hline $\begin{array}{l}\text { Maturity } \\
\text { Level }\end{array}$ & $\begin{array}{c}\text { Academic Process } \\
\text { Management }\end{array}$ & $\begin{array}{c}\text { Process } \\
\text { Attributes }\end{array}$ \\
\hline 5-Optimized & $\begin{array}{l}\text { - Institutional Evaluation } \\
\text { Management } \\
\text { - External Evaluation } \\
\text { Management } \\
\text { - Academic Performance } \\
\text { Management }\end{array}$ & $\begin{array}{l}\text { PAR5 - The } \\
\text { process is } \\
\text { continuously } \\
\text { optimized }\end{array}$ \\
\hline $\begin{array}{l}\text { 4-Managed } \\
\text { and Measured }\end{array}$ & $\begin{array}{ll}\text { - } & \text { Regulatory } \\
\text { Requirements } \\
\text { Management } \\
\text { - Certificate Management } \\
\text { - Teacher Body } \\
\text { Management } \\
\text { - Collaboration } \\
\text { - Management } \\
\text { - Alumni Relationship } \\
\text { Management }\end{array}$ & $\begin{array}{lr}\text { PAR4 - } & \text { The } \\
\text { process } & \text { is } \\
\text { controlled } & \end{array}$ \\
\hline 3-Managed & $\begin{array}{l}\text { - } \text { Education Program } \\
\text { Management } \\
\text { - Debts Management } \\
\text { - Payment Management }\end{array}$ & $\begin{array}{lr}\text { PAR3 - The } \\
\text { process } \\
\text { measured }\end{array}$ \\
\hline $\begin{array}{l}2 \text { - Partly } \\
\text { Managed }\end{array}$ & $\begin{array}{l}\text { - } \text { Content Management } \\
\text { - Student Support } \\
\text { Management } \\
\text { - Application }\end{array}$ & $\begin{array}{l}\text { PAR2 - The } \\
\text { process } \\
\text { implementation } \\
\text { is managed }\end{array}$ \\
\hline
\end{tabular}




\begin{tabular}{|l|l|l|}
\hline & $\begin{array}{l}\text { Management } \\
\text { - Assessment and } \\
\text { Attendance } \\
\text { Management }\end{array}$ & \\
\hline 1- Informal & • Financial Plan & \\
& Management & $\begin{array}{l}\text { PAR1 - The } \\
\text { process Admission } \\
\text { achieves the } \\
\text { defined } \\
\text { purpose } \\
\text { Management } \\
\text { - Application Offering } \\
\text { Management } \\
\text { - Program Structure } \\
\text { Management }\end{array}$ \\
& \\
\hline
\end{tabular}

For each level it is possible to define a profile for an educational institution that can be:

- Informal: In this level the educational institutions are characterized by a tendency to give up process in crisis situations and the inability to repeat success. There is also a clear separation between academic and administrative departments.

- Partly Managed: In this level the educational institutions can make short term planning but still have clear separation between academic and administrative areas.

- Managed: In this level the educational institutions are characterized for having medium term planning, clearly defined processes and the academic and administrative departments feels that belong in the same institution.

- Managed and Measured: In this level the educational institutions develop long term planning and have the ability to run their process with defined goals. The management is supported by key indicators and errors are identified and fixed.

- Optimized: In this level the educational institutions are characterized by the continuously improvement of their process bring new ideas and technologic improvement.

\section{Situational Diagnostics Phase}

The first deployment phase of this Maturity Model is the Situational Diagnostics. Divided into two subphases, the goal of this step is to know in detail the reality of the institution and to assess what level of maturity in their processes are. In the first sub-phase will be applied questionnaires with questions related to the Expected Results Process (ERP) of all 22 academic processes.

During the situational diagnostics process, the strategic, tactical and operational employees of the education institution will answer about each goal set and they need to prove if the organization achieves that goal with evidences.

In the context of this Maturity Model, evidence is an artifact that demonstrates clearly and objectively that the practice is or is not performed at the institution.

The evidence may be:

- Standards, procedures and ordinances of the institution to determine rules and process flows;

- Process flow definition documents resulting from methodologies of process mapping;

- Systems screens and reports;

- Other documents that have the institutional credibility and are valid at the time of situational diagnostics;

Below are some examples of evidence that can be used to answer the research of this Maturity Model.

- Reporting systems;

- Spreadsheets;

- Official Documents (Ordinances, Regulations, and others);

- System display.

For this process there are five statuses for each goal set:

- Yes and I have evidence - When the institution has a practice and I can prove it through some evidence;

- Yes and I have no evidence - Where the institution owns the practice and I cannot prove it by any evidence;

- No, and I have evidence - When the institution does not have to practice and I can prove its nonexistence by any evidence;

- No, and I have no evidence - When the institution does not have the practice and I cannot prove its nonexistence by any evidence

- Not applicable - If the institution does not use the concept presented. E.g. If the question is focused on "Research and Extension" but the institution is a college that has no such obligation;

After a compilation of responses of all employees about one goal set, it's possible to define which stage that goal set is (showed in the Table 1)

The first benefit after situational diagnostics phase is to know the maturity of each process and be able to plan improvements for each process. The other important benefit is the possibility to compare two moments of the institution or compare two or more institutions and make a benchmark evaluation. 
Table 3 shows the comparison between three campuses of one higher education institution.

Table 3. Results of each academic process for each campus

\begin{tabular}{|c|c|c|c|}
\hline Process & $\begin{array}{c}\text { Campu } \\
\text { s } 1\end{array}$ & $\begin{array}{c}\text { Campu } \\
\quad s 2 \\
\end{array}$ & $\begin{array}{c}\text { Campu } \\
\text { s } 3 \\
\end{array}$ \\
\hline $\begin{array}{l}\text { Education Program } \\
\text { Management }\end{array}$ & $14 \%$ & $46 \%$ & $41 \%$ \\
\hline $\begin{array}{l}\text { Teacher Practice } \\
\text { Management }\end{array}$ & $40 \%$ & $46 \%$ & $45 \%$ \\
\hline $\begin{array}{l}\text { Financial Plan } \\
\text { Management }\end{array}$ & $40 \%$ & $50 \%$ & $46 \%$ \\
\hline $\begin{array}{l}\text { Regulatory Requirements } \\
\text { Management }\end{array}$ & $41 \%$ & $50 \%$ & $46 \%$ \\
\hline $\begin{array}{l}\text { Student Relationship } \\
\text { Management }\end{array}$ & $45 \%$ & $50 \%$ & $60 \%$ \\
\hline $\begin{array}{l}\text { Space Available } \\
\text { Management }\end{array}$ & $46 \%$ & $53 \%$ & $61 \%$ \\
\hline $\begin{array}{l}\text { New Students Apply } \\
\text { Management }\end{array}$ & $46 \%$ & $57 \%$ & $63 \%$ \\
\hline $\begin{array}{l}\text { Program Structure } \\
\text { Management }\end{array}$ & $50 \%$ & $60 \%$ & $69 \%$ \\
\hline Content Management & $50 \%$ & $61 \%$ & $69 \%$ \\
\hline Admission Management & $50 \%$ & $63 \%$ & $70 \%$ \\
\hline Certificate Management & $53 \%$ & $69 \%$ & $79 \%$ \\
\hline $\begin{array}{l}\text { Assessment and } \\
\text { Attendance Management }\end{array}$ & $57 \%$ & $70 \%$ & $81 \%$ \\
\hline $\begin{array}{l}\text { Collaboration } \\
\text { Management }\end{array}$ & $59 \%$ & $79 \%$ & $63 \%$ \\
\hline Debts Management & $60 \%$ & $81 \%$ & $69 \%$ \\
\hline $\begin{array}{l}\text { Institutional Evaluation } \\
\text { Management }\end{array}$ & $61 \%$ & $82 \%$ & $50 \%$ \\
\hline $\begin{array}{l}\text { External Evaluation } \\
\text { Management }\end{array}$ & $63 \%$ & $53 \%$ & $50 \%$ \\
\hline $\begin{array}{l}\text { Alumni Relationship } \\
\text { Management }\end{array}$ & $69 \%$ & $57 \%$ & $53 \%$ \\
\hline $\begin{array}{l}\text { Academic Performance } \\
\text { Management }\end{array}$ & $70 \%$ & $60 \%$ & $57 \%$ \\
\hline $\begin{array}{l}\text { Human Resources } \\
\text { Management }\end{array}$ & $79 \%$ & $40 \%$ & $59 \%$ \\
\hline $\begin{array}{l}\text { Strategic and } \\
\text { Organizational } \\
\text { Management }\end{array}$ & $81 \%$ & $40 \%$ & $53 \%$ \\
\hline $\begin{array}{l}\text { social responsibility } \\
\text { management }\end{array}$ & $82 \%$ & $41 \%$ & $57 \%$ \\
\hline Research management & $83 \%$ & $82 \%$ & $14 \%$ \\
\hline Total Average & $56 \%$ & $59 \%$ & $57 \%$ \\
\hline
\end{tabular}

Analyzing this table and comparing the results of each academic process by each campus we can realize which campus has the best practice in each process and we can use these practices to improve to academic process of other campuses. Using the best practices of each campus in the three campuses, the total average of all campuses will improve for $69 \%$.

Important considerations about the diagnoses phase:
- Does not take into consideration regional particularities of each institution in evaluating the process maturity;

- $\quad$ Process are evaluated regardless of which ERP is used;

- Is not the direct goal of the situational diagnostics phase to make changes in the analyzed processes;

- $\quad$ Performance indicators must be applied to the processes so it can be measured and improved;

\section{Conclusion}

This paper proposes a situational diagnostic and a maturity model for academic management processes in private institutions of higher education, having as its foundation four basic elements: Processes of Academic Management, Expected Results of Process (ERPs), Attributes of Processes Attributes Results (APRs) and Maturity Scale. From this model higher education institutions can evaluate and know the level of maturity of each process of academic management. With this information, managers of these institutions can compare their institution against the market or compare institutions within the same group. Additionally, it allows for quality improvement of their processes, unification of these processes when possible and, consequently, the reduction of operating costs. A maturity model, unprecedented in the education market, will contribute to improve the quality of education services and strengthening the position of private institutions.

\section{References}

[1] SILVA, D. F. A. Modelo de Maturidade de Processos de Gestão Acadêmica em Instituições Privadas de Ensino Superior. 2009. 103 p. Dissertação (Mestrado em Tecnologia) - Centro Estadual de Educação Tecnológica Paula Souza, São Paulo, 2009.

[2] TUCCI, Mario; CELLESI, Luca. Higher education quality in Florence University: First analysis of a self assessment model implementation. Firenze, 2001.

[3] MCGREW, Anthony. “A global society?”. In: Stuart Hall; David Held e Tony McGrew (orgs). Modernity and its futures. Cambridge: Polity Press/Open University Press, 1992:61-116.

[4] SILVA, Daniel Fernando Antonucci e; CABRAL, Rodrigo Becke; COLENCI JR, Alfredo. Modelo de Maturidade de Processos de Gestão 
Acadêmica para Instituições Privadas de Ensino Superior. XIX Enangrad - Curitiba, 2008.

[5] SOFTEX. MPS.BR - Melhoria de Processo do Software Brasileiro: Guia Geral (Versão 1.2). http://www.softex.br/mpsBr/_guias/default.asp.

Access date: 10 June, 2008.

[6] [ISO/IEC 15504-5, 2006] - International Organization for Standardization and International Electrotechnical Commission. ISO/IEC 15504-5: Information Technology - Process Assessment - Part 5: An exemplar Process Assessment Model, Genebra: ISO, 2006.

[7] PAULK, Mark C. et al. The Capability Maturity Model for Software. Carnegie Mellon University, Pittsburgh, PA, April 1996.

[8] SEI. CMMI: Capability Maturit Model Integration. http://www.sei.cmu.edu/cmmi/general/. Access date: 20 April, 2009.

[9] Silva, Daniel Fernando Antonucci e; Cabral, R. B.. Maturity Model for Process of Academic Management. In: I-Society, 2010, London. I-Society, 2010 